\title{
High Secretion of Beta-HCG by Squamous Cell Carcinoma of the Lung in a Postmenopausal Female
}

\author{
Linzhi Liu, Chenguang Shang, Xiaohui Wang, Yan Zhang* \\ Department of Obstetrics and Gynecology, Peking University First Hospital, Beijing, China \\ Email: ^shamruck@126.com
}

How to cite this paper: Liu, L.Z., Shang, C.G., Wang, X.H. and Zhang, Y. (2016) High Secretion of Beta-HCG by Squamous Cell Carcinoma of the Lung in a Postmenopausal Female. Open Journal of Obstetrics and Gynecology, 6, 669-675.

http://dx.doi.org/10.4236/ojog.2016.612084

Received: August 9, 2016

Accepted: November 1, 2016

Published: November 4, 2016

Copyright $\odot 2016$ by authors and Scientific Research Publishing Inc. This work is licensed under the Creative Commons Attribution International License (CC BY 4.0).

http://creativecommons.org/licenses/by/4.0/

\begin{abstract}
With the development of research in tumor, some of them have been found to secrete beta-human chorionic gonadotropin ( $\beta$-HCG) ectopically and lung cancer is one of them. Generally, lung cancer secreting $\beta$-HCG is mostly undifferentiated small cell carcinoma. Here, we report a rare case of squamous cell lung cancer secreting high level of $\beta$-HCG in a postmenopausal female. The tumor secreted $\beta$-HCG, measuring $16,500 \mathrm{mIU} / \mathrm{ml}$. The patient presented with hemoptysis and postmenopausal bleeding. Pathological examination of CT-guided biopsy and investigations could not tell whether it was primary squamous cell lung cancer or choriocarcinoma with lung metastasis, to be responsible for the high level of $\beta$-HCG. The chemotherapy in the early stage seemed to be effective, but not good in the late stage. Then she underwent a right pulmonary middle lobectomy and the pathological examination finally confirmed the diagnosis of poorly differentiated squamous cell carcinoma. The auxiliary chemotherapy made a decreased $\beta$-HCG. Only a few reports of squamous cell lung cancer secreting that high level of $\beta$-HCG can be found in the literature.
\end{abstract}

\section{Keywords}

Lung, Squamous Cell Carcinoma, $\beta$-HCG

\section{Introduction}

Globally, lung cancer is the second leading cause of cancer death in women, following breast cancer [1]. And squamous cell lung cancer is still one of the most common and main types of lung cancer. Generally, it arises in the airway epithelium of a main or lober bronchus. $\beta$-HCG is usually secreted by germ cell tumors, such as choriocarcinoma, 
and is rarely produced by other tumors. In the literature, limited case reports have discussed secretion of $\beta$-HCG in lung cancers, especially in non-small cell lung cancers. But it is not common to encounter squamous cell lung cancer secreting $\beta$-HCG. We here present a rare case of it. And to our knowledge, there are no cases that have been reported, in which squamous cell lung cancer secrets that high level of $\beta$-HCG ectopically.

\section{Case Presentation}

A 54-year-old postmenopausal female, presented with six days of hemoptysis and three days of postmenopausal bleeding. She had coughed for one month with no obvious predisposing causes and had two vaginal bleedings happened five and two years ago respectively. She had hypertension for two years not exposed to any medicines and the highest blood pressure was 140/90 mmHg. Diabetes mellitus was first diagnosed. Her menarche and menopause age were 16 and 48 years old and the menstruation was normal. She reported that she had four pregnancies with two miscarriages and no history of hydatidiform mole. No history of smoking or drinking. She was in a fair condition except for a weight loss about $5 \mathrm{~kg}$ during a half year.

Gynecological examination appeared no obvious abnormity in uterus and adnexa. Transvaginal ultrasonography revealed that the endometrium was $5 \mathrm{~mm}$ thick with echo heterogeneity. A well-defined mass with higher density, measuring $8.0 \times 5.8 \mathrm{~cm}$, in the right middle lobe of lung was detected on chest X-ray and lobulation and apparent thorn were not found. Chest enhanced computed tomography scan (Figure 1) confirmed the mass and showed a $12.0 \mathrm{~cm} \times 6.5 \mathrm{~cm} \times 8.0 \mathrm{~cm}$ space occupying lesion, which corresponded to lung metastasis. It is more likely that the tumor thrombosis located in the confluent locus of veins of right middle lobe lung, superior pulmonary vein and left atrium. Obstructive pneumonia was detected in right middle lobe. Abdominal CT showed

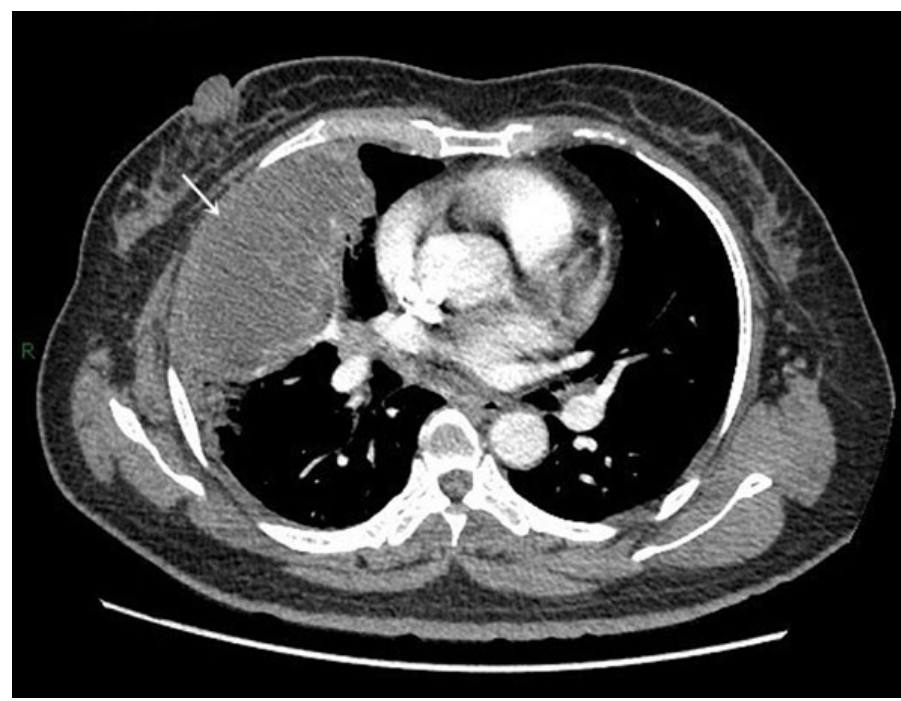

Figure 1. Computed tomography scan showed a massive mass in the right lung (white arrow), measuring $12.0 \mathrm{~cm} \times 6.5 \mathrm{~cm} \times 8.0 \mathrm{~cm}$. 
infarct of spleen and solid lesions in bilateral adnexa. Serum $\beta$-HCG was 16,500 $\mathrm{mIU} / \mathrm{ml}$ and the tumor marker, such as CA125, CYFRA21-1, NSE and TPA, were increased.

After a cycle of chemotherapy, regimen of BEP (Bleomycin + Etoposide + Nedaplatin), PET-CT reexamination revealed that lesions in double accessories and spleen, as well as tumor thrombosis, had disappeared. Chest X-ray showed the mass had reduced to $7.6 \times 6.7 \mathrm{~cm}$ (Figure 2). Then CT-guided percutaneous transthoracic biopsy was performed and the pathological examination (Figure 3) showed that replacement of normal lung tissue by coagulative necrosis with fibrous tissue and acute and chronic

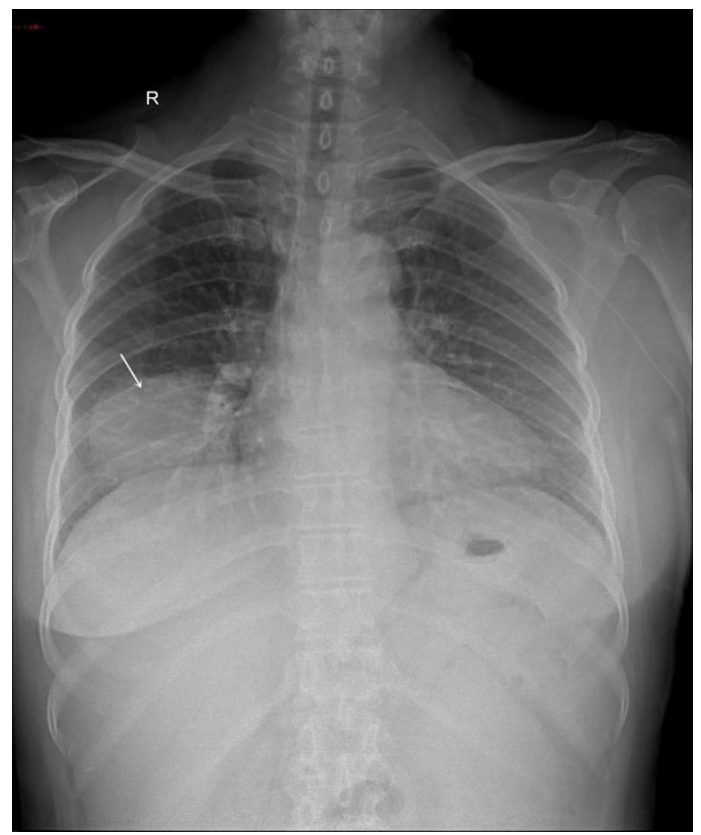

Figure 2. Chest radiography noted a well-defined mass (white arrow), measuring $7.6 \times 6.7 \mathrm{~cm}$, with higher density.

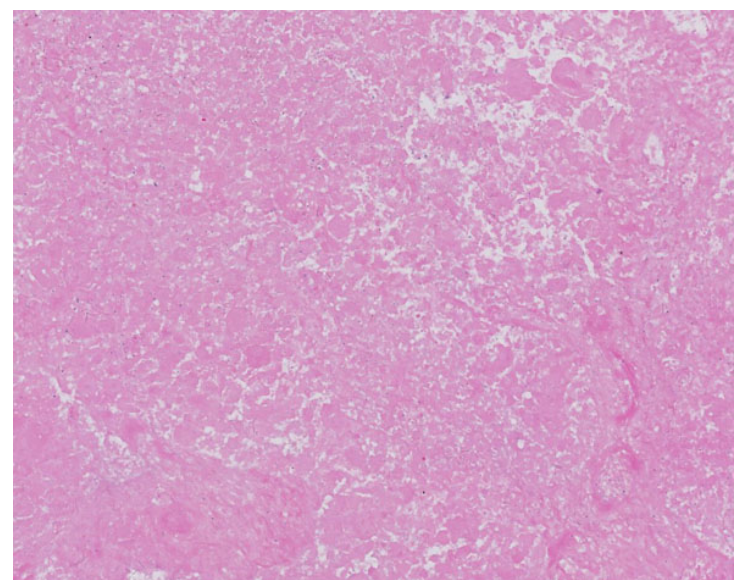

Figure 3. Coagulative necrosis could be seen in the lung tissue ( $\mathrm{H}$ and $\mathrm{E}$ staining $\times 200$ ). 
lymphocytes infiltrating around. Residual outlines of the coagulative necrosis cells were also visible. An immune-histochemical examination indicated that AE1/AE3, CK7, and HCG were positive and CK20, TTF1 and HPL were negative, which were consistent with the traits of trophoblast cells. So choriocarcinoma with lung metastasis was favored considering that the coagulative necrosis was the residual outlines of choriocarcinoma cells. However, squamous cell lung cancer still could not be excluded. The patient strongly refused surgical treatment and insisted on chemotherapy. During the chemotherapy, side effects, such as thrombocytopenia, hyperglycemia and digestive symptoms appeared but were relieved after symptomatic approaches treatment.

After seven cycles of chemotherapy, enhanced-chest CT (Figure 4) showed the lesions in lung reduced to $4.9 \times 3.5 \times 3.9 \mathrm{~cm}$. The previous five chemotherapy treatments leaded to a gradual drop of $\beta$-HCG from $16,500 \mathrm{mIU} / \mathrm{ml}$ to $107.92 \mathrm{mIU} / \mathrm{ml}$. However, the value went up to $151.91 \mathrm{mIU} / \mathrm{ml}$ since the latter two cycles of chemotherapy were administrated. Thus, a right pulmonary middle lobectomy was performed. The pathological examination (Figure 5) was also checked and showed a poorly differentiated squamous cell carcinoma of right lung. The auxiliary chemotherapy, regimen of GEM + DDP (Gemcitabine + Cisplatin), was then conducted. After two cycles, we found new lesions in lung CT (Figure 6). The disease progressed because of chemo-resistance. New regimen was initiated with Nedaplatin $130 \mathrm{mg}$ D1 + Etoposide $100 \mathrm{mg}$ D1-5 + Bleomycin $15 \mathrm{mg} \mathrm{D1}, 3,5 \mathrm{Q} 3 \mathrm{~W}$. Serum $\beta$-HCG after each cycle of the chemotherapy, gradually decreased to normal level. The chemotherapy course went successfully. Our 18-month follow-up showed that she had no signs of recurrence.

\section{Discussion}

This postmenopausal female with a high level of $\beta$-HCG-secreting squamous cell lung cancer initially couldn't be distinguished from choriocarcinoma with lung metastasis,

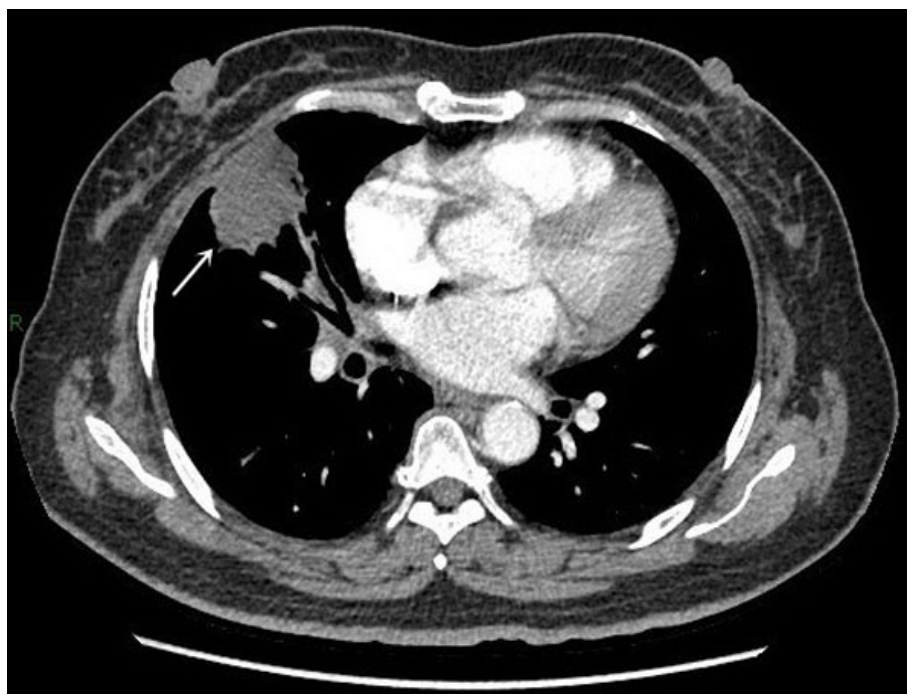

Figure 4. Computed tomography scan displayed that the mass (white arrow) in the lung had narrowed to $4.9 \times 3.5 \times 3.9 \mathrm{~cm}$. 


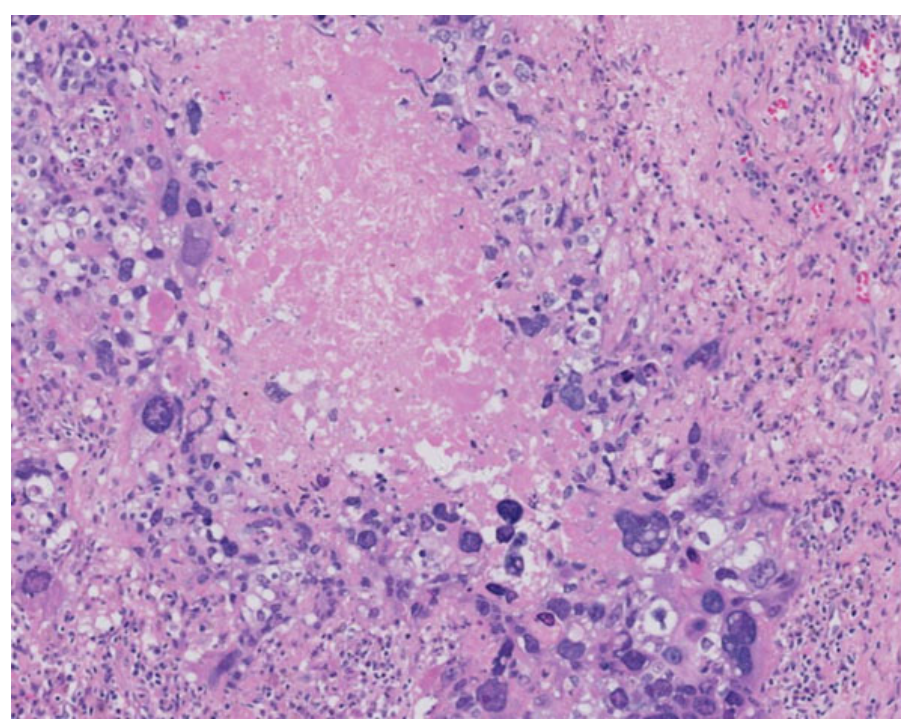

Figure 5. Biopsy of lung tissue showing squamous cancer cells $(\mathrm{H}$ and E staining $\times 400)$.

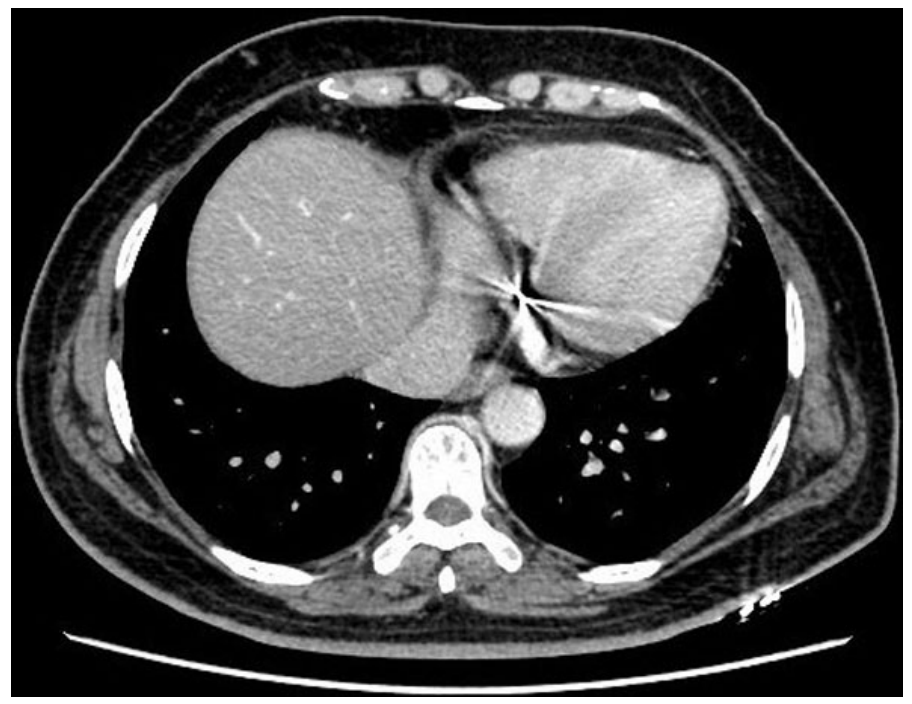

Figure 6. Computed tomography scan discovered new lesions, presented as scattered higher density spots in lung.

because we had not encountered any cases of squamous cell lung cancer secreting that high level of $\beta$-HCG before that or read any reports in literature. Then chest enhanced computed tomography scan, abdominal CT, PET-CT, chest X-ray, lung biopsy and chemotherapy were performed. We eliminated a choriocarcinoma with lung metastasis based on histological examinations after right pulmonary middle lobectomy and finally diagnosed a poorly differentiated squamous cell carcinoma of right lung. Suffered from a chemo-resistance of auxiliary chemotherapy, she was then performed with a new regimen of chemotherapy and reacted well. Finally, $\beta$-HCG returned to normal level and according to the follow-up, there is no recurrence of the disease. All of the process indicated that the $\beta$-HCG secretion derived from squamous cell lung cancer. 
Squamous cell lung cancer is one of the most common human cancers in the world today, which accounts for $20 \%-30 \%$ of non-small cell lung cancer [2] [3]. There is no characteristic appearance in computed tomography (CT) examination, so a combination with pathological and immune-histochemical examination is needed to make a definite diagnosis. Lung in pathological status can produce various hormones, while secreting $\beta$-HCG is quite rare. Often, a majority of lung cancer secreting $\beta$-HCG are undifferentiated small cell carcinoma, as well as squamous cell carcinoma. Generally, the secretion of $\beta$-HCG by squamous cell carcinoma varied from $5 \mathrm{mIU} / \mathrm{ml}$ to several hundred. To our knowledge, the highest secreting level of $\beta$-HCG by SCC that had been reported so far, was $12,238 \mathrm{mIU} / \mathrm{ml}$ [4]. These levels are significantly lower than the level observed in our patient.

The mechanism of $\beta$-HCG production by the tumor cells is not well understood. Several studies have tried to look into $\beta$-HCG production. It is an atavism for malignant tumor secreting $\beta$-HCG, which is much similar to embryo cells or fetal cells in biological character. The ectopic $\beta$-HCG secretion is an effect of tumor transformation rather than the cause. In a study published from Japan, mRNA transcripts of the beta gene were detected in lung cancer tissues, and the result of the study was that $\beta$-HCG production was noted in malignantly transformed lung cells [5].

How $\beta$-HCG works is also not clear. Some studies have indicated that it acts as an autocrine or paracrine growth factor or both by inhibiting apoptosis [6]. While, some researchers have suggested that $\beta$-HCG can specifically stimulate the growth of tumors regarding it as autocrine hormone. It is said that it acts as growth factor like nerve growth factor (NGF), platelet-derived growth factor (PDGF) and transforming growth factor (TGF). Tumor can regulate self-growth independently by secreting $\beta$-HCG. Also, the secretion may be associated with tumor microenvironment inhibiting the activation of immune cells, such as NK, T cell, macrophages and so on, which degrades the immunological activity or even loses. All of these may be the causes of immunological tolerance toward carcinoma [7]. Serum $\beta$-HCG shows a certain specificity and sensitivity for the diagnosis of lung cancer, and can be a helpful diagnostic method.

Based on reports in the medical literature, paraneoplastic syndromes secreting high level of $\beta$-HCG in squamous cell lung cancer are very uncommon. So, in a patient with high serum level of $\beta$-HCG and lesions in the lung, the differential diagnosis including primary lung cancer and choriocarcinoma with lung metastasis are needed. Therefore, knowing this rare but possible high level of $\beta$-HCG by lung tumors may speed out the gynecological work-up and the reevaluation of the histological samples, which may minimize the delay in the care of these patients.

\section{Conclusion}

We reported a squamous cell lung cancer secreting $\beta$-HCG measuring $16,500 \mathrm{mIU} / \mathrm{ml}$ in a postmenopausal female. The patient had a very high level of $\beta$-HCG compared with other cases reported in the literature. 


\section{References}

[1] Mao, Y.S., Yang, D., He, J. and Krasna, M.J. (2016) Epidemiology of Lung Cancer. Surgical Oncology Clinics of North America, 25, 439-445.

[2] Zhang, N.N. and Wang, A.M. (2013) Progression on Molecular Pathology of Squamous Cell Lung Cancer. Chinese Clinical Oncology, 18, 947-950.

[3] Piperdi, B., Merla, A. and Perez-Soler, R. (2014) Targeting Angiogenesis in Squamous Non-Small Cell Lung Cancer. Drugs, 74, 403-413. http://dx.doi.org/10.1007/s40265-014-0182-z

[4] Yoshida, J., Nagai, K., Nishimura, M., Takahashi, K., Kakinuma, R., Nshiwaki, Y., et al. (2000) Secretion of hCG/ $\beta$-hCG by Squamous Cell Carcinoma of the Lung in a 31-Year-Old Female Smoker. Japanese Journal of Clinical Oncology, 30, 163-166. http://dx.doi.org/10.1093/jjco/hyd028

[5] Yokotani, T., Koizumi, T., Taniguchi, R., Nakagawa, T., Isobe, T., Yoshimura, M., et al. (1997) Expression of Alpha and Beta Genes of Human Chorionic Gonadotropin in Lung Cancer. International Journal of Cancer, 71, 539-544. http://dx.doi.org/10.1002/(SICI)1097-0215(19970516)71:4<539::AID-IJC6>3.0.CO;2-V

[6] Iles, R.K. (2007) Ectopic hCG Beta Expression by Epithelial Cancer: Malignant Behavior, Metastasis and Inhibition of Tumor Cell Apoptosis. Molecular and Cellular Endocrinology, 260-262, 264-270. http://dx.doi.org/10.1016/j.mce.2006.02.019

[7] He, K., Xu, J.-S. and Song, L.-P. (2005) Progress in Study on Ectopic Expression of HCG in Malignant Tumors. Foreign Medical Sciences (Section of Maternal and Child Health), 16, 420-422.

\section{Submit or recommend next manuscript to SCIRP and we will provide best service} for you:

Accepting pre-submission inquiries through Email, Facebook, LinkedIn, Twitter, etc. A wide selection of journals (inclusive of 9 subjects, more than 200 journals)

Providing 24-hour high-quality service

User-friendly online submission system

Fair and swift peer-review system

Efficient typesetting and proofreading procedure

Display of the result of downloads and visits, as well as the number of cited articles

Maximum dissemination of your research work

Submit your manuscript at: http://papersubmission.scirp.org/

Or contact ojog@scirp.org 